\title{
SELECTED PROBLEMS OF NONINVASIVE OOZE DREDGING IN THE PROTECTED AREAS OF PORT DOCKS
}

\section{WYBRANE PROBLEMY NIEINWAZYJNEGO OCZYSZCZANIA UMOCNIEŃ DNA W BASENACH PORTOWYCH}

\author{
Teresa Abramowicz-Gerigk ${ }^{1)}$, Zbigniew Burciu ${ }^{1)}$, Wiktor Stefurak ${ }^{2)}$ \\ ${ }^{1)}$ Gdynia Maritime University, ${ }^{2)}$ Wroclaw University of Technology \\ e-mail:tagerigk@am.gdynia.pl,zbj@am.gdynia.pl,wiktor.stefurak@pwr.wroc.pl
}

\begin{abstract}
The paper presents the analysis of the ooze dredging concepts in the protected areas of harbour docks. The proposed method and system for ooze dredging are dedicated to all types of seabed protection, but the main concern are the geotextile mattresses, not resistant to mechanical damages. Due to the large seabed areas covered with this type of protection the effective method of noninvasive ooze dredging should be based on the use of a technical vessel for underwater works. The result of the analysis is the concept of the method and system for ooze dredging including in particular the mechanism for the automatic holding of the suction-dredge head in the proper distance from the seabed protection surface - the leading wheel truck and buoyancy-ballast system.
\end{abstract}

Keywords: ooze dredging, suction-dredge head

Streszczenie: Tematem publikacji jest analiza możliwości usuwania osadów dennych $z$ umocnionych powierzchni dna $w$ basenach portowych. Metoda oraz system usuwania osadów zostaty zaproponowane dla wszystkich rodzajów umocnień dna, jednak przede wszystkim skupiono się na usuwaniu osadów z powierzchni materacy geotekstylnych, wrażliwych na uszkodzenia mechaniczne. Ze względu na duze powierzchnie tych umocnień, efektywna metoda nieinwazyjnego usuwania osadów powinna się opierać na wykorzystaniu statku technicznego przystosowanego do prowadzenia prac podwodnych. Wynikiem przeprowadzonej analizy jest koncepcja metody $i$ systemu usuwania osadów, obejmująca $w$ szczególności mechanizm automatycznego utrzymywania odległości głowicy ssaco-urabiajacej - kołowy wózek prowadzacy i system wypornościowobalastowy.

Stowa kluczowe: usuwanie osadów dennych, głowica ssaco-urabiająca 
Selected problems of noninvasive ooze dredging in the protected areas... Wybrane problemy nieinwazyjnego oczyszczania umocnien dna...

\section{Introduction}

The operation of large vessels at small depth to draft ratios in ports is the reason of scouring and large volume of sand and sludge drifting due to the propellers and thrusters jets. The maintenance of technical depth is related to periodical dredging and cleaning works $[1,3,11]$. To reduce the influence of propeller jets on seabed protection the limits of engine power used by vessels in ports are introduced. For example the assumed limits for the big ferries maneuvering near the quay are about $25 \%$ to $45 \%$ of their maximum power $[5,9]$. These restrictions are not always adhered as the higher values of power can be used during manoeuvres in emergency situations. The result is seabed scouring, degradation of seabed protection, degradation of berth constructions, drift of sludge and sand onto the protected surfaces near the quay walls.

The damages caused by the high velocity jets are dependent on the type of seabed protection $[6,7]$. The inspections of seabed protection involve de jure the precise depth soundings in the areas close to the quays once a year [3]. In practice at the beginning of a new vessel operation the time between inspections follows from the design recommendations, and then it is dependent on the decisions of Maritime Administration and Port Authority [2]. The operational experience shows the necessity of much more frequent measurements and maintenance works - cleaning and dredging than it is stated in the rules.

The methods of ooze dredging in the areas of seabed protection shall be appropriate to the ooze characteristics, construction and material of seabed protection [1]. Nowadays the serious problem is sludge removing from the surfaces of geotextile mattresses, not resistant to mechanical damages.

Due to the large seabed areas covered with this type of protection in ports of Gdansk and Gdynia there is a need to develop an effective method of noninvasive ooze dredging, based on the application of the specially designed technical vessel for underwater works.

\section{Operational and technical objectives of ooze dredging system}

There are different types of seabed protection used in ports to prevent scouring: stone riprap, colloidal concrete stone asphalt with riprap, quarry stone pattern grouted with asphalt bitumen, asphalt mattresses, stone-filled gabions, mattresses made of steel or concrete blocks, mattresses made of geotextile bags filled with sand, stones or concrete. The choice of type of seabed protection is dependent on the assumed propeller jet velocities, technical water depth, geological structure of seabed and the necessity of soft bottom effect, to decrease the required under keel clearance.

The main factors influencing the quality of seabed protection in port docks are both technology and frequency of cleaning and maintenance works [3, 10]. In case of not protected seabed in the area not closed to the quays the hydraulic suction dredgers can be used for the ooze dredging. This type of dredgers has a trailed or pushed suction head connected to the suction pipeline. 
In ooze dredging the methods of sludge loosening and dredging are related to the solid concentration in the sediments. In dependence of loosening method there are suction dredgers with mechanical cultivator of transverse or parallel axis to the suction pipeline. The hydraulic dredgers can loose and dredge the sludge by suction the sludge with some amount of surrounding water. The capacity rate of the loosen sludge to water should be about 1:5.

The suction heads for the liquid and semi-liquid sediments can be equipped with the buoyancy drum to control the working depth. The water jet nozzles and mechanical devices are used to put the dredged material settled on the bottom into suspension. In dependence on dredging depth the underflow pump can be placed in the suction pipeline, suction head or onboard the vessel.

The big problem in ports is ooze dredging of sediments and sand from the surfaces of geotextile mattresses. The mattresses are made of 2,0x $1,5 \times 0,5 \mathrm{~m}$ polypropylene textile bags filled with sand and tied together by ropes. The bags are arranged on the geotextile fabric pinned to the seabed to stabilize it and keep stability of the bags. The edges of the geotextile fabric are covered with sandy or coarse gravel.

The maintenance works must be very careful due to the surface not resistant to mechanical loads. The traditional dredge heads for cutting, lifting and collecting the sludge cannot be used there. In practice these works are carried out manually by divers.

The technology of cleaning the seabed in port areas is different than in open waters. It can be assumed that the water depth along the quay does not change a lot and the collected ooze layer is not very thick. The waves in port docks are much smaller than outside the breakwater, therefore the necessary compensation of the changes of distance to the seabed is smaller.

\section{Concept of a noninvasive ooze dredging system}

Analysing the possible solutions of ooze dredging system for seabed protections cleaning all types of seabed protections used in ports have been assumed. The system should consist of the following main subsystems (Figure 1):

- independent floatation unit (technical vessel) - providing the independent floatability of the whole system,

- suction-dredge head - loosening and suction of the sludge from the seabed surface,

- connective system - system connecting the suction head with the ship hull and supporting the pipelines with media,

- suction-dredge head positioning system - system positioning the suction-dredge head with reference to the seabed, preventing the surface of seabed protection from mechanical damage,

- sludge transport system - system consisting of sludge suction pump, piping and sludge storage tank. 
Selected problems of noninvasive ooze dredging in the protected areas... Wybrane problemy nieinwazyjnego oczyszczania umocnien dna...

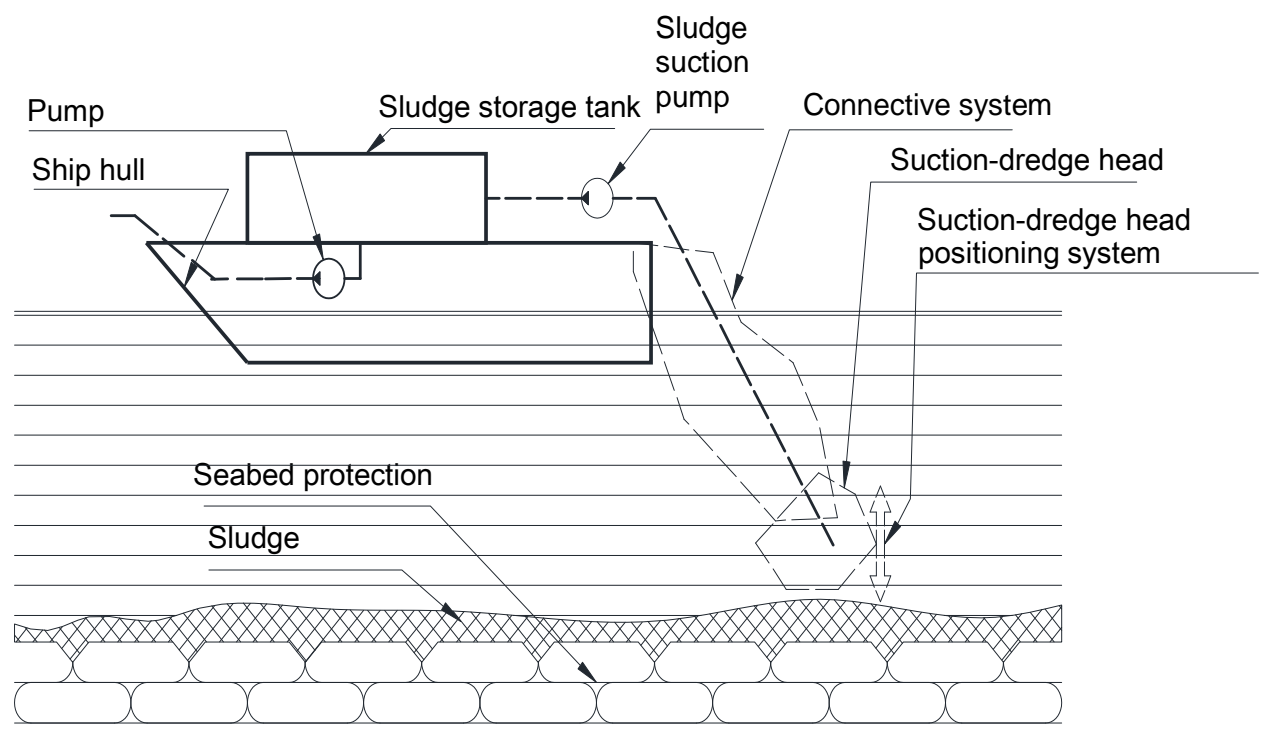

Fig. 1 The general outline of noninvasive ooze dredging system.

The ooze dredging in the protected areas should be carried out with full monitoring. Before dredging the particular area should by scanned and all obstructions should be examined and removed by divers. The costs of the supporting works (Table 1) [2,8] carried out before and after ooze dredging, should be included in the total cost of the cleaning works.

Table 1. Example of unit costs of seabed inspections in port

\begin{tabular}{|l|l|c|}
\hline Lp. & \multicolumn{3}{|c|}{ Type of costs } & Costs \\
\hline 1 & $\begin{array}{l}\text { Sounding approved by National Hydrographic } \\
\text { Services in the 50 m stripe along the quay. }\end{array}$ & $45,00 \mathrm{PLN} / 1000 \mathrm{~m}^{2}$ \\
\hline 2 & $\begin{array}{l}\text { Inspections of protected seabed with sludge } \\
\text { measurements and seabed damages with the divers' } \\
\text { certificate. }\end{array}$ & $1,00 \mathrm{PLN} / 1 \mathrm{~m}^{2}$ \\
\hline 3 & $\begin{array}{l}\text { Inspections of protected seabed with sludge } \\
\text { measurements and seabed damages with the divers' } \\
\text { certificate, graphical stocktaking and numerical } \\
\text { record. }\end{array}$ & $1,50 \mathrm{PLN} / 1 \mathrm{~m}^{2}$ \\
\hline
\end{tabular}

The sediments loosening technology should be adequate to their characteristics. Usually the sediments on the seabed protection surface are not firm. There are several methods of sediments loosening and transport. 
Sludge loosening with the external water jet is presented in figure 2.

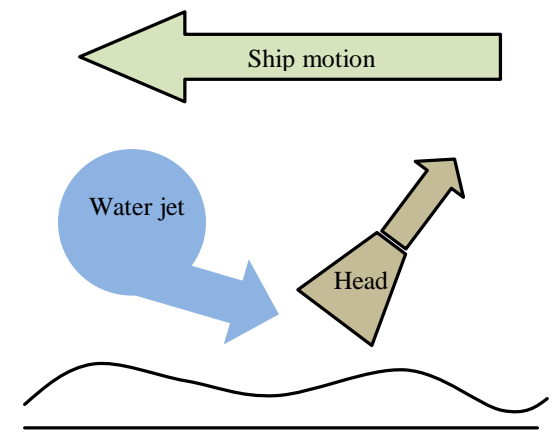

Sludge loosening opposite to dragging direction

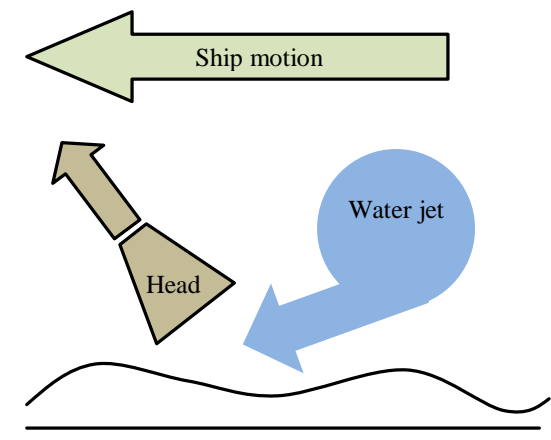

Sludge loosening in dragging direction

Fig. 2 Water jetting - sludge loosening using the water jet

The sludge loosening is made by water jet generated by the pump, for example a submersible pump. The jet directed to the seabed puts in suspension the material settled on the bottom, loosened sediments are lifted into the suction head. In dependence on the position of horizontal components of velocities of water jet and ship the loosening is carried out in dragging direction or opposite to dragging direction.

In case of light sediments, like ooze, not coherent with the surface of seabed protection, they can be lifted by the motion of surrounding water for example the motion forced by a swirler (Figure 3).

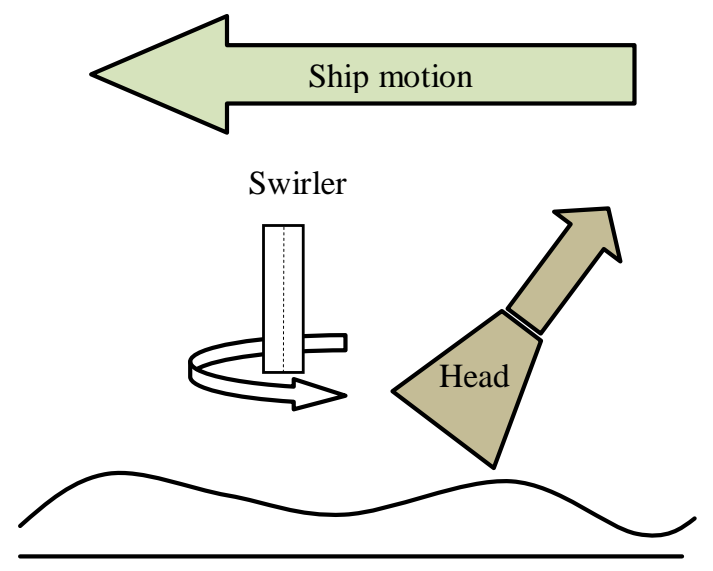

Fig. 3 Sludge loosening by a swirler generating eddies in the surrounding water 
Selected problems of noninvasive ooze dredging in the protected areas... Wybrane problemy nieinwazyjnego oczyszczania umocnien dna...

The most energy efficient method is the direct dredging using suction head only (Figure 4), however it requires the proper determination of the suction force in terms of the physical characteristics of sediments and distance between the suction head and surface of seabed protection.

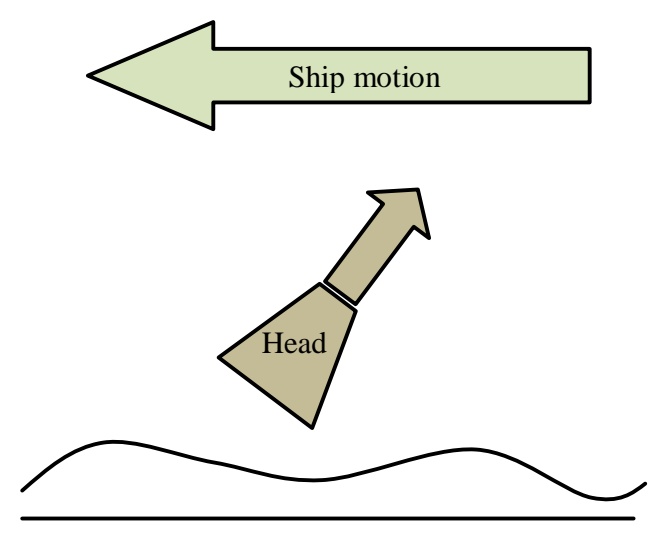

Fig. 4 Direct suction of sediments.

The connection of dredge-suction head with the floating hull is dependent on the method of suction head positioning. The most popular construction is the ladder, jointly fastened to the ship hull (Figure 5).

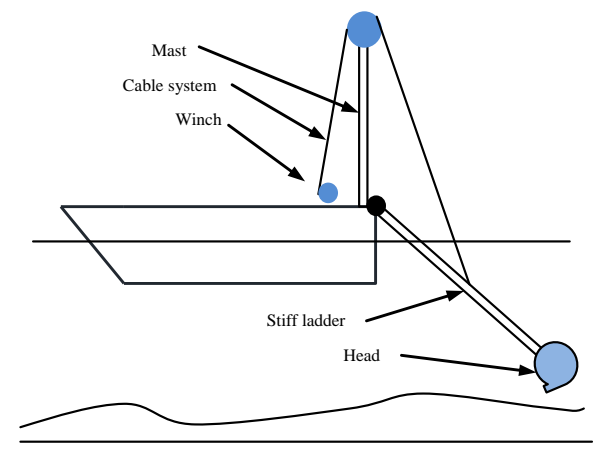

Stiff ladder

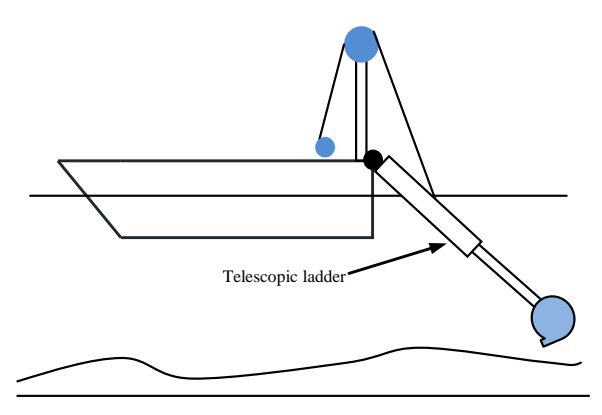

Telescopic ladder

Fig. 5 System connecting suction head with the ship hull

The dredge-suction head is fixed to the submerged end of the ladder. The ladder is lifted and lowered by the winch and system of ropes.

The construction of the rigid ladder is simple however its operation requires a tall mast. 
The ladder of a variable length can be operated using shorter mast, but its construction is complicated, because both the lifting mechanism and mechanism of changing the ladder length are necessary. For the $12 \mathrm{~m}$ water depth the ladder length should be about $16-17 \mathrm{~m}$, therefore the multi joint ladder can be considered as one of the solutions.

The lifting mechanism should have a position control function of the suction head. One of the possible solutions of positioning the suction head over the seabed at the distance satisfying the proper conditions for suction the sludge is the online measurement and correction of the distance between the head and ooze surface (Figure 6).

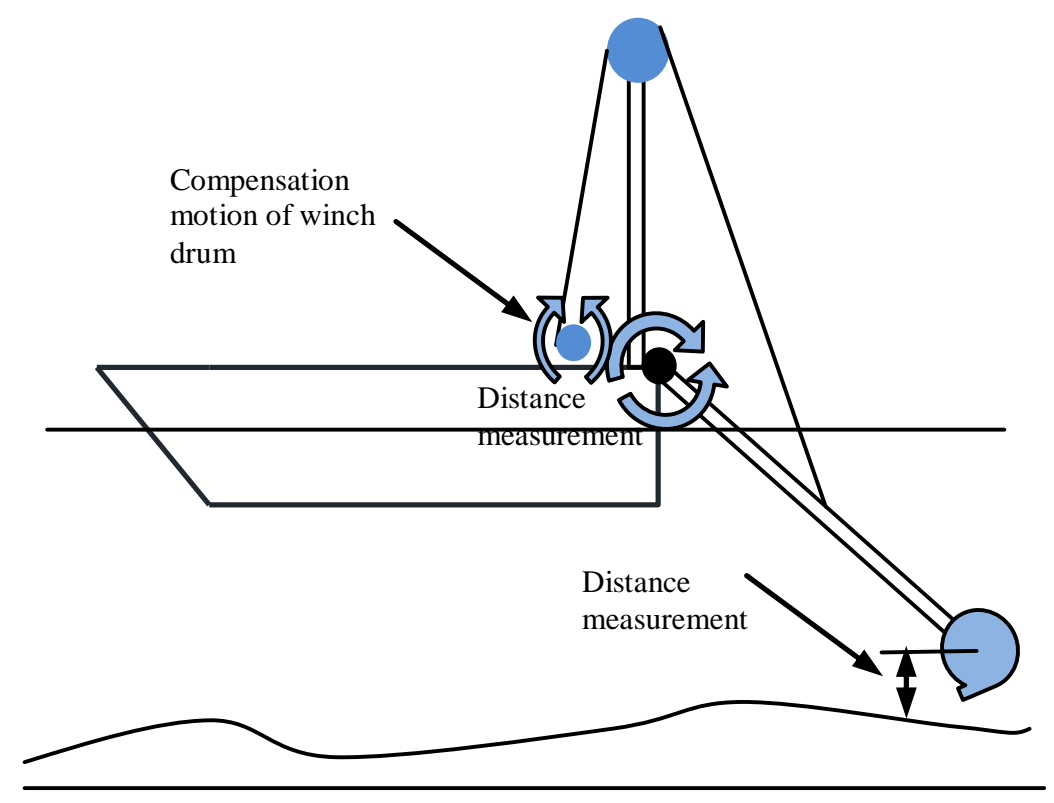

Fig. 6 The compensation the suction-dredge head position

Another possible solution utilizing the precise pressure meters in the pipeline is practically impossible due to the local changes of pressure induced by the sucked water, required detection sensitivity for the ooze layer thickness about $0.3 \mathrm{~m}$ and possibility of delayed reaction which can cause the contact of the suction head with bottom surface.

The working conditions of the analyzed system are more stable than for the normal dredging works due to the calm water in port docks, however the vertical differences of the surface can be about $1 \mathrm{~m}$ height. This determines the expected mode of the head guiding motion over the seabed. The mechanism for the selfcontrol of the distance, based on the wheel truck supporting the suction head has been proposed (Figure 7). 

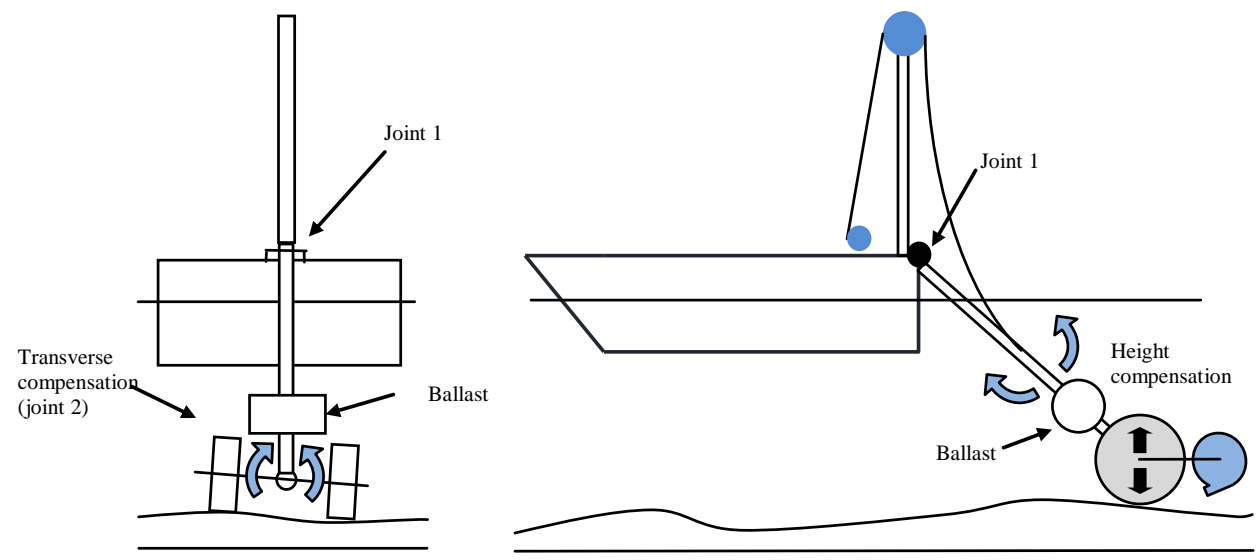

Fig. 7 The proposed system of leading the suction head over the seabed

To ensure the proper contact of the wheels with the ground not causing damage to the bottom protection, particularly important in the case of the geotextile surface, the buoyancy-ballast tank is proposed. Loose cables of ladder lifting system allow for its free swinging in the mounting joint (Figure 7 - joint 1), according to a variable depth of the head immersion. This method of automatic compensation of the distance from the seabed to the suction head eliminates the interference caused by the hull roll, pitch and vertical motions.

The changes of the sediments layer thickness, along the movement of the vessel are compensated by the transverse compensation joint (Figure 7 - joint 2).

The design of a suction-dredge head, design of the wheels, bearings and buoyancyballast system are the main problems which should be solved within the technical assumptions. The proposed solution removes the disadvantages of suction-dredge head positioning used in traditional dredgers. The advantages are as follows:

- inexpensive and reliable positioning technology,

- no servos and servo control system,

- immediate and continuous response to the irregular changes of seabed relief,

- positioning od suction-dredge head without external energy.

These advantages result with:

- smaller degree of complexity, higher reliability of the system,

- less cost of the investment compared to the traditional dredging system,

- lower operating costs (no control system, no electricity consumption).

In the analysed design the typical layout of a suction dredger has been considered - the suction and force pump used to dredge the sludge and lift it onto the deck at a height of about 12-15 meters. The hydrated sludge can be collected in a tank installed onboard and then transferred to the discharge area. 


\section{Conclusion}

The basic problem of sludge removal from the surface of seabed protection in ports is the development of an efficient automated method of positioning the suctiondredge head during dredging the sediments.

The most significant difference of the proposed design is a method for maintaining a constant distance between the suction-dredge and seabed. The proposed solution is much simpler technically, reliable in operation, cheaper for investments and in operation. On the basis of engineering analysis, the method of non-invasive dredging in harbors has been rated as more efficient and reliable than the current methods of sludge removal especialy the manual handling of sediment by divers with a water jet [4]. The big advantage is the smooth collecting of sludge without preventing its dispersion in the water.

\section{References}

[1] Abramowicz-Gerigk T., Burciu Z., Ocena stanu systemu umocnień dna w rejonie nabrzeży portowych. Problemy Eksploatacji nr 1/2011, str. 7-16.

[2] Abramowicz-Gerigk T. Wpływ monitorowania obciążeń umocnień dna i nabrzeża w rejonie cumowania statków na koszty eksploatacji basenów portowych. Logistyka nr. 3/2014, str. 1-9

[3] Dziennik Ustaw Nr 101 poz. 645 z dnia 6 sierpnia 1998 r. Rozporządzenie Ministra Transportu i Gospodarki Morskiej z dnia 1 czerwca 1998 r. w sprawie warunków technicznych, jakim powinny odpowiadać morskie budowle hydrotechniczne i ich usytuowanie.

[4] Kogure Y., Hodohara Y., Yano S., Kamachi K. An innovative ooze dredging for environmental preservation. ISARC 2006: The 23rd International Symposium on Automation and Robotics in Construction 2006, str. 648-653.

[5] Mazurkiewicz B., Wiśniewski F., Zespół roboczy zasad projektowania budowli morskich. Morskie budowle hydrotechniczne. Zalecenia do projektowania i wykonywania Z1-Z 45. Wydanie V. Fundacja Promocji Przemysłu Okrętowego i Gospodarki Morskiej. Gdańsk 2008.

[6] PIANC Guidelines for the design of armoured slopes under open piled quay walls. Report of working group 22, supplement to PIANC Bulletin 96, Brussels, Belgium, 1997.

[7] PIANC Guidelines for berthing structures related to thrusters. Report of working group 48 of PIANC, Brussels, Belgium (2010).

[8] Pismo okólne Nr $1 \mathrm{z}$ dnia 4 stycznia 2005 r. w sprawie ogłoszenia tekstu jednolitego załącznika do Zarządzenia Wewnętrznego Nr 3 Dyrektora Urzędu Morskiego w Szczecinie z dnia 21 marca 2003r. w sprawie opłat za czynności i usługi Urzędu Morskiego w Szczecinie, Urząd Morski w Szczecinie, Wydział Organizacyjny Znak: O-021/1/1/05 Szczecin, dnia 04 stycznia 2005 
Selected problems of noninvasive ooze dredging in the protected areas... Wybrane problemy nieinwazyjnego oczyszczania umocnień dna...

[9] Verheij H., Sas M., Hermans, M., Schmidt E., Guidance on the Design of Berthing Structures Related to the Flow Velocities in Ship Thrusters. Scour and Erosion. Edited by Susan E. Burns; Shobha K. Bhatia; Catherine M. C. Avila; Beatrice E. Hun, 2010.

[10] Whitehouse R., Scour at marine structures: a manual for practical applications Thomas Telford publications, London 1998.

[11] www.portgdansk.pl/o-porcie/badania-osadow.
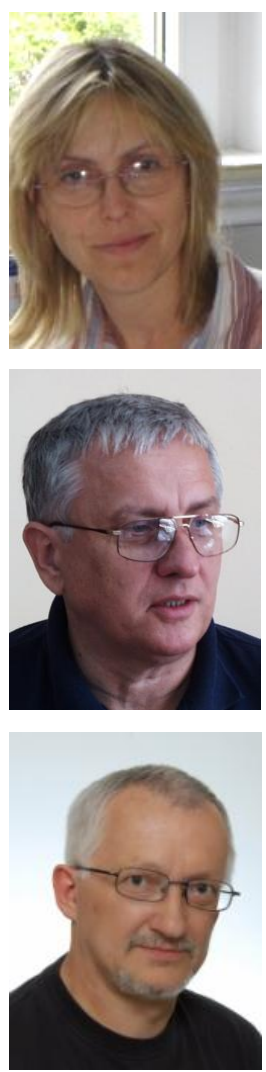

Dr hab. inz. Teresa Abramowicz-Gerigk, Akademia Morska w Gdyni (Gdynia Maritime University, Faculty of Navigation). Specialist in modelling of ship dynamics and safety of maritime transportation. Author or coauthor of more than 80 publications, both in Polish and English. Coordinator and general contractor and of national and international $R \& D$ projects.

Prof. dr hab. inż. kpt. ż.w. Zbigniew Burciu, Akademia Morska w Gdyni (Gdynia Maritime University, Faculty of Navigation). Specialist in modelling of safety and reliability of Search and Rescue operations and safety of maritime transportation. Author and coauthor of more than 100 publications, both in Polish and English. Coordinator of national and international $R \& D$ projects. Member of Scientific-Technical Board at Chief of the National Civil Defense.

Dr inz. Wiktor Stefurak, Politechnika Wroctawska, Wydziat Mechaniczny. (Technical University of Wroclaw, Mechanical Faculty) Specialist in mechanical engineering, designer. Author and coauthor of 6 patents and more than 60 publications, both in Polish and English, general contractor of national and international $R \& D$ projects. 